\title{
Antidepressant, Anxiolytic and Antinociceptive Activities of Constituents from Rosmarinus Officinalis
}

\author{
Abeer Abdelhalim ${ }^{1,2}$, Nasiara Karim ${ }^{3}$, Mary Chebib ${ }^{1}$, Talal Aburjai ${ }^{4}$, Imran Khan ${ }^{3}$, Graham, A.R. Johnston ${ }^{5}$ and Jane R. \\ Hanrahan $^{1}$ \\ ${ }^{1}$ Faculty of Pharmacy, University of Sydney, Sydney, Australia; ${ }^{2}$ Faculty of Science, Taibah University, Almadina \\ Almonawara, Saudi Arabia; ${ }^{3}$ Department of Pharmacy, University of Malakand, Chakdara Pakistan; ${ }^{4}$ Faculty of \\ Pharmacy, University of Jordan, Amman, Jordan; ${ }^{5}$ School of Medical Sciences, Pharmacology, The University of \\ Sydney, Sydney, Australia.
}

Received, June 8, 2015; Accepted, August 31, 2015; Published, September 15, 2015.

\begin{abstract}
Purpose. Rosmarinus officinalis, traditionally known as rosemary, has been widely used in traditional medicines and has long been known as the herb of remembrance. However, few studies have investigated the effects of non-volatile components of rosemary on central nervous system function. Methods. Fractionation of $R$. officinalis led to the isolation of salvigenin, rosmanol and cirsimaritin, which were investigated in mouse models of acute toxicity, antinociception (tail immersion and hot plate tests), depression (tail suspension and forced swim tests) and anxiety (elevated plus maze and light/dark box paradigms). Results. Rosmanol, cirsimaritin and salvigenin were not found to exhibit any signs of acute toxicity $(50-200 \mathrm{mg} / \mathrm{kg})$, but elicited antinociceptive, antidepressant and anxiolytic activities. Conclusion. Rosmanol, cirsimaritin and salvigenin, all previously shown to have biphasic modulation of $\mathrm{GABA}_{\mathrm{A}}$ receptors, demonstrated CNS activity in mouse models of antinociception, antidepressant and anxiolysis. The anxiolytic activity of all three compounds was not ameliorated by flumazenil, but was inhibited by pentylenetetrazol, suggesting a mode of action via $\mathrm{GABA}_{\mathrm{A}}$ receptors at a site other than the high affinity benzodiazepine binding site.
\end{abstract}

This article is open to POST-PUBLICATION REVIEW. Registered readers (see "For Readers") may comment by clicking on ABSTRACT on the issue's contents page.

\section{INTRODUCTION}

Rosmarinus officinalis, traditionally known as rosemary, grows wild in most Mediterranean countries [1]. It is often cultivated for its great quantity of essential oils used in the perfume industry and as a flavouring agent. Rosemary has been widely used in traditional medicines and it has been found to have significant antioxidant activity [2]. It has long been known as the herb of remembrance [3], and it has been reported that memory is improved with the use of $R$. officinalis $[4,5]$. Although the mechanism of its nootropic effects is unknown, extracts of $R$. officinalis have been found to enhance the production of the nerve growth factor (NGF) [6], which functions as a neurotrophic molecule for magnocellular cholinergic neurons in basal forebrain nuclei, which are specifically lost in Alzheimer disease (AD) [7], and inhibit acetylcholinsesterase in rat brain [5].

Several constituents of $R$. officinalis have also been investigated for their activity in the central nervous system. Thujone has been shown to modulate $\mathrm{GABA}_{\mathrm{A}}$ receptors [8]. Rosmarinic acid has been shown to have antidepressive activity in mice models $[9,10]$, and at low doses to elicit anxiolytic-like activity in the rat plus-maze task [11]. The aerial parts of $R$. officinalis have also been reported to possess antinociceptive activity [1]. In rotenone-induced neurotoxicity of cultured dopaminergic cells carnosol significantly increased the amount of tyrosine hydroxylase, an enzyme that is down-regulated in Parkinson's disease [12].

$\gamma$-Aminobutyric acid (GABA) is the primary inhibitory neurotransmitter in the mammalian central nervous system (CNS) activating neurons through a number of pharmacologically and structurally different receptor subtypes: ionotropic $\mathrm{GABA}_{\mathrm{A}}$ and $\mathrm{GABA}_{\mathrm{C}}$ and metabotropic $\mathrm{GABA}_{\mathrm{B}}$ receptors. It plays an important role in the balance between neuronal inhibition and excitation, thus regulating many physiological and psychological processes $[13,14]$. The $\mathrm{GABA}_{\mathrm{A}}$ receptor is possibly the most complex member of the ligandgated ion channel superfamily containing binding sites not only for GABA but also for general anaesthetics, barbiturates, picrotoxin, and

Corresponding Author:. Faculty of Pharmacy, University of Sydney, Sydney, Australia; E-mail:

jane.hanrahan@sydney.edu.au 
neurosteroids, a number of flavonoids modulate $\mathrm{GABA}_{\mathrm{A}}$ receptors in CNS [15] and two different sites for benzodiazepines [16]. Cirsimaritin has previously been reported to bind weakly to the benzodiazepine site on $\mathrm{GABA}_{\mathrm{A}}$ receptors [17] and we have previously reported the functional activity of a ursolic acid, rosmanol, cirsimaritin, salvigenin and carnosol on $\mathrm{GABA}_{\mathrm{A}}$ receptors expressed in Xenopus oocytes [18] Salvigenin, rosmanol, cirsimaritin, ursolic acid, carnosol, hesperidin and nepitrin were isolated from Rosmarinus officinalis. The current study reports the effects of the nonvolatile constituents, salvigenin, rosmanol, cirsimaritin (Figure 1), in mouse models of toxicity, analgesia, antidepressant and anxiolytic activity.

\section{MATERIAL AND METHODS}

\section{Plant Materials}

The dried Rosmarinus officinalis plants were purchased from herbal markets located in Amman. The plants were identified by Prof. Dawud AlEisawi (Department of Biological Sciences, Faculty of Science, University of Jordan). Voucher specimens were deposited at the herbarium of the University of Jordan. Fractionation and purification of the dried $R$. officinalis led to the isolation of salvigenin, rosmanol, cirsimaritin, ursolic acid, carnosol, hesperidin and nepitrin.

\section{Chemicals, Materials, Instrumentation and Drugs}

All chemicals used were purchased from Aldrich Chemical Co. Ltd (St Louis, MO, USA) and were of highest commercially available purity. Silica gel for column chromatography (CC) was performed on silica gel (Merck silica gel $60 \mathrm{H}$, particle size 5 - $40 \mu \mathrm{m}$ ) and Sephadex LH-20 gel. Thin layer chromatography (TLC) was performed on Merck aluminium backed plates, pre-coated with silica (0.2 mm, 60F254). UV-Spectra were recorded on Hitachi U-2000 double beam UV/Vis Spectrophotometer. Mass spectra were carried out on a ThermoFinnigan (Waltham, MA, USA) PolarisQ Ion Trap system using a direct exposure probe. Nuclear magnetic resonance ${ }^{1} \mathrm{H}$ NMR and ${ }^{13} \mathrm{C}$ NMR spectra were recorded at 400 and 100 $\mathrm{MHz}$, respectively on a Varian Gemini spectrometer (Palo Alto CA, USA). Melting points were determined using a Stuart (Stone, Staffordshire, UK) SMP10 melting point apparatus. Diazepam was kindly donated by the Department of Pharmacy, University of Peshawar. Imipramine, DMSO, Tween solution (TWEEN® 80), tramadol hydrochloride and flumazenil (Sigma-Aldrich, USA) and pentylenetetrazol (Tokyo chemical industries Co Ltd) were purchased for the study. All chemicals and solvents used in this research were of analytical grade.

\section{Preparation of the Extracts and Solvent Fractionation}

The dried materials ( $5 \mathrm{~kg}$ ) were ground into fine powder and defatted by extraction with petroleum ether $(40 \mathrm{~L})$ at room temperature for 7 days. The remaining materials were then extracted by ethanol (3 times, 10 days each, $50 \mathrm{~L}$ ) at room temperature. The combined crude ethanolic extracts were evaporated under vacuum. The resulting crude extract was partitioned between chloroform and water $(1: 1 \mathrm{v} / \mathrm{v})$. The chloroform layer was evaporated under reduced pressure to give a solid residue, which was partitioned between $10 \%$ aqueous methanol as one phase, and $n$-hexane as the other phase. The methanolic extract was then extracted with ethyl acetate to give the ethyl acetate extract.<smiles>COc1ccc(C2=CC(=O)c3c(cc(OC)c(OC)c3O)C2)cc1</smiles>

Salvigenin<smiles>CC(C)c1cc2c(c(O)c1O)[C@@]13CCCC(C)(C)C1C(O2)C3O</smiles>

Rosmanol<smiles>COc1cc2c(c(O)c1OC)C(=O)C=C(c1ccc(O)cc1)C2</smiles>

Cirsimaritin

Figure 1: Constituents of Rosmarinus officinalis used in this study 


\section{Isolation of Constituents}

The ethyl acetate extract $(25 \mathrm{~g})$ was chromatographed on a silica gel column $(\Phi 28 \times 8$ $\mathrm{cm}$ ) eluted with a gradient of chloroform/methanol with increasing polarity resulting in five fractions (RI-RV). Each fraction was further purified by a combination of column chromatography and preparative thin layer chromatography using suitable solvent systems. The addition of ethyl acetate to the methanolic extract of $R$. officinalis yielded an impure solid that was filtered and washed with methanol to afford ursolic acid (3hydroxy-urs-12-en-28-oic acid). An impure solid precipitated after the addition of chloroform to fraction RI that was then recrystallized from methanol to give white crystals, which were identified as carnosol. Fraction RII gave an impure solid that upon addition of chloroform gave salvigenin (5-hydroxy-6,7,4'-trimethoxyflavone). Cirsimaritin (5,4'-dihydroxy-6,7dimethoxyflavone) was obtained upon treating fraction RIII with methanol. Addition of methanol to fraction RIV yielded an impure solid that was then purified by thin layer chromatography $(2 \%$ $\mathrm{MeOH} / \mathrm{CHCl}_{3}$ ) to yield rosmanol. Salvigenin, rosmanol, cirsimaritin had spectroscopic data identical to that previously reported for these compounds isolated from Salvia trilobia [18].

Salvigenin: light yellow powder; UV $\lambda_{\max }(\mathrm{MeOH})$ nm: 332 (Band I), 277 (Band II); +NaOMe, 327, (Band I), 278 (Band II); $+\mathrm{AlCl}_{3}, 349$ (Band I), 300 (Band II); +HCl, 349 (Band I), 299 (Band II); ESMS m/z (\%): 350.9 (100), 328.9 (4); ${ }^{1} \mathrm{H}-\mathrm{NMR}$ $\left(\mathrm{DMSO}-d_{6}\right) \delta \mathrm{ppm}: 12.86(1 \mathrm{H}, \mathrm{s}, 5-\mathrm{OH}), 8.06(2 \mathrm{H}$, d, $\left.J=8.8 \mathrm{~Hz}, \mathrm{H}-2^{\prime}, \mathrm{H}_{-} 6^{\prime}\right), 7.11$ (2H, d, $J=8.8 \mathrm{~Hz}, \mathrm{H}-$ 3', H-5'), 6.95 (1H, s, H-8), 6.93 (1H, s, H-3), 3.92 (3H, s, 7-OMe), 3.85 (3H, s, 4'-OMe), 3.72 (3H, s, 6-OMe); ${ }^{13} \mathrm{C}-\mathrm{NMR}$ (DMSO- $\left.d_{6}\right) \delta \mathrm{ppm}: 182.7(\mathrm{C}-4)$, 164.1 (C-2), 162.9 (C-4'), 159.2 (C-7), 153.1 (C-5), 152.5 (C-9), 132.4 (C-6), 128.8 (C-2', C-6'), 123.2 (C-1'), 115.1 (C-3', C-5'), 105.6 (C-10), 103.8 (C3), 92.1 (C-8), 60.5 (6-OMe), 56.9 (7-OMe), 50.1 (4'-OMe).

Rosmanol: light white powder; ESMS $m / z$ (\%): 314.9 [M-CH3] $^{+}$(100), 369.0 (93), 301.0 (28), 347 (8); ${ }^{1} \mathrm{H}-\mathrm{NMR}\left(\mathrm{DMSO}-d_{6}\right) \delta \mathrm{ppm}: 6.68$ (H, s, H-14), 5.08 (1H, d, J=4.4 Hz, H-7), $4.13(1 \mathrm{H}, \mathrm{t}, J=4 \mathrm{~Hz}$, H-6), 3.21 (1H, sept, $J=1.6 \mathrm{~Hz}, \mathrm{H}-15), 2.59$ (1H, d, $J=14.4 \mathrm{~Hz}, \mathrm{H}-1 \alpha), 2.57$ (1H, m, H-5), 2.53 (1H, ddd, $J=13.8,4.4 \mathrm{~Hz}, \mathrm{H}-1 \beta), 1.60$ (1H, m, H-2 $\alpha$ ),

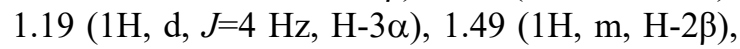
1.21(1H, ddd, $J=13.4,3 \mathrm{~Hz}, \mathrm{H}-3 \beta), 1.25(3 \mathrm{H}, \mathrm{d}$, $J=1.6 \mathrm{~Hz}, \mathrm{H}-17), 1.11$ (3H, d, $J=1.6 \mathrm{~Hz}, \mathrm{H}-16)$, 0.94 (3H, s, H-18), 0.79 (3H, s, H-19); ${ }^{13} \mathrm{C}-\mathrm{NMR}$
(DMSO-d $d_{6} \delta$ ppm: $175.2(\mathrm{C}-20), 143.9$ (C-11), 143.4 (C-12), 134.6 (C-13), 128.8 (C-8), 122.2 (C9), 115.2 (C-14), 80.0 (C-6), 67.7 (C-7), 55.0 (C5), 47.9 (C-10), 41.1 (C-3), 34.3 (C-4), 32.3 (C-18), 29.2 (C-1), 26.7 (C-15), 23.3 (C-17), 23.0 (C-16), 21.3 (C-19), 18.9 (C-2).

Cirsimaritin: light yellow crystals, m.p. 267-269 ${ }^{\circ} \mathrm{C}$; UV $\lambda_{\max }(\mathrm{MeOH}) \mathrm{nm}: 333$ (Band I), 275 (Band II); +NaOMe, 387, (Band I), 272 (Band II); $+\mathrm{AlCl}_{3}$, 353 (Band I), 299 (Band II); +HCl, 353 (Band I), 299 (Band II); ESMS m/z (\%): 336.8 (100), 314.9 (43), 300.9 (4); ${ }^{1} \mathrm{H}-\mathrm{NMR}$ (DMSO- $d_{6}$ ) $\delta$ ppm: 12.91 (1H, s, 5-OH), 7.94 (2H, d, J=8.8 Hz, H-2', H-6'), $6.91\left(2 \mathrm{H}, \mathrm{d}, J=8.8 \mathrm{~Hz}, \mathrm{H}-3^{\prime}, \mathrm{H}-5^{\prime}\right), 6.91$ (1H, s, H8), 6.82 (1H, s, H-3), 3.90 (3H, s, 7-OMe), 3.71 (3H, s, 6-OMe); ${ }^{13} \mathrm{C}-\mathrm{NMR}$ (DMSO- $\left.d_{6}\right) \delta \mathrm{ppm}$ : 182.7(C-4), 164.5 (C-2), 161.9 (C-4'), 159.0 (C-7), 153.1 (C-5), 152.5 (C-9), 132.3 (C-6), 129.0 (C-2', C-6'), 121.4 (C-1'), 115.4 (C-3', C-5'), 105.5 (C-10), 103.1 (C-3), 92.0 (C-8), 60.5 (6-OMe), 56.9 (7OMe).

\section{Animals}

Male Swiss mice with a weight range of 20 to $30 \mathrm{~g}$ were purchased from the National Institute of health (NIH) Islamabad, Pakistan. Animals were housed in the Department of Pharmacy, University of Malakand's animal house with fresh water and standard food available ad libitum. The animals were maintained at a 12 hours light and dark cycle and with room temperature of $22-25^{\circ} \mathrm{C}$ in the animal house. All animal procedures have been approved by the Departmental Animal Ethical Committee (DAEC/PHARM/2012/13) and were conducted according to the UK animal scientific procedure act, 1986.

\section{Acute toxicity}

The acute toxicity study was conducted according to the modified method described by Adebiyi \& Abatan [19]. Swiss albino mice (25-30g) were randomly divided into ten groups $(n=6)$. Animals were fasted overnight, but had access to water ad libitum, and then treated intraperitonealy with salvigenin, rosmanol or cirsimaritin $(50,150$ and $200 \mathrm{mg} / \mathrm{kg})$. Mice in the control group received 10 $\mathrm{ml} / \mathrm{kg}$ i.p. of vehicle $(0.9 \% \mathrm{w} / \mathrm{v})$. Animals were carefully observed for any signs of toxic effects during the first 6 hours after the treatment and then carefully monitored for the subsequent 66 hours, (3-days observation) for any changes in behaviors including grooming, hyperactivity, sedation, respiratory arrest, convulsion, increased or decreased motor activity and mortality, if any. 


\section{Assessment of analgesic activity \\ Tail Immersion Method}

Mice were divided into eleven groups $(n=6)$. The lower $5 \mathrm{~cm}$ portion of the tail was immersed in a beaker of water maintained at $55 \pm 0.5^{\circ} \mathrm{C}$ [20]. The time in seconds for tail withdrawal from the water was taken as the reaction time, with a cut-off time of immersion at $10 \mathrm{sec}$. The reaction time was measured 1 hour before and after administration of salvigenin, rosmanol and cirsimaritin (1, 30, and $100 \mathrm{mg} / \mathrm{kg}$, i.p) or vehicle (10 mL/kg, i.p.). Tramadol as the positive control $(20 \mathrm{mg} / \mathrm{kg})$ was administered subcutaneously, $30 \mathrm{~min}$ before the test.

\section{Hot-plate test}

The hot-plate test was used to measure the response latencies in mice according to the previously described method [21]. The mice were screened by placing them on a hot metal plate maintained at $50 \pm 0.05{ }^{\circ} \mathrm{C}$. Thermal nociception was measured through discomfort demonstrated by jumping, withdrawal of paws or licking of paws. In the prescreening test, only those mice which offered response within $15 \mathrm{~s}$ were selected for the experiment. The prescreened mice were divided in 11 groups $(n=6)$. Mice were injected with the vehicle $(10 \mathrm{~mL} / \mathrm{kg}$, i.p. $)$ or drug as reported in table 2. The response latencies were recorded at 0,30 , 60, 90 and 120 minutes. Percent inhibition was calculated as follows.

$\%$ inhibition $=$

(((Mean reaction time (Vehicle))-(Mean reaction

time (drug))) / Mean reaction time (drug)) X 100

\section{Assessment of anxiolytic activity Elevated plus maze (EPM)}

The apparatus consisted of two open arms $(30 \mathrm{~cm}$ x $5 \mathrm{~cm})$ and two closed arms $(30 \mathrm{~cm}$ x $5 \mathrm{~cm} \mathrm{x} 15$ $\mathrm{cm})$ made of black plexiglass connected by an open central platform $(5 \mathrm{~cm} \times 5 \mathrm{~cm})$ and elevated $40 \mathrm{~cm}$ from ground level. A raised ledge $(3 \mathrm{~mm}$ high and $1 \mathrm{~mm}$ thick) surrounded the perimeter of the open arms. Mice were injected with vehicle or drugs, and 20 minutes later placed in the center of the apparatus facing an open arm and allowed to explore the maze for $5 \mathrm{~min}$. An arm entry was defined by having all four paws inside the arm. All sessions were videotaped by a camera positioned above the maze, and at the end of the test, the number of arm entries and time spent in arms were recorded. To assess the involvement of the GABAergic system, animals were either pretreated i.p. with vehicle or pentylenetetrazol (PTZ, 20 $\mathrm{mg} / \mathrm{kg}$ ) [22], prior to treatment with salvigenin, rosmanol or cirsimaritin. The $\%$ of open arm entries and the $\%$ of time spent in the open arms were recorded as a measure of anxiety state [23].

\section{Light/dark box test (LDB)}

The light/dark apparatus consists of an acrylic box of dimensions $44 \mathrm{~cm}$ x $21 \mathrm{~cm}$ x $21 \mathrm{~cm}$, divided into a small dark compartment (one-third) and a large illuminated compartment (two-thirds), the division between zones contains an opening of $6 \mathrm{~cm} \times 3 \mathrm{~cm}$. The box possesses 16 light beams, 11 in the lit area and 5 in the dark area, which detect the movement of the animal. The box is connected to a computer that records the number of transitions between areas, latency to the first transition, time and activity in each zone and total activity in a $5 \mathrm{~min}$ session. An increase in the exploration of the lit area is associated with an anxiolytic effect; as such, two parameters were selected as a measure of anxiety: the time spent in the lit compartment and the total number of transitions [24].

\section{Assessment of antidepressant activity The tail suspension test}

Mice were hung by their tail on the tail hanger using sticky tape for tail fixation, at approximately $1 \mathrm{~cm}$ from the end of the tail. The hanger was fixed in the black plastic box $(20 \times 20 \times 45 \mathrm{~cm})$ with the opening at the top front. The distance between the hanger to floor was approximately $40 \mathrm{~cm}$. The mouse was suspended in the air by its tail and the immobility time was recorded over a period of 5 minutes. The duration of immobility was defined as the absence of all movement except for those required for respiration [25].

\section{The forced swim test}

The forced swim test was carried out in a glass cylinder (diameter $20 \mathrm{~cm}$, height $30 \mathrm{~cm}$ ) filled with water to the height of $20 \mathrm{~cm}$. The water temperature was approximately $25-28^{\circ} \mathrm{C}$. Mice were gently placed into the water and the immobility time was recorded by an observer a period of 5 minutes. Immobility was defined as absence of all movement and remaining floating passively in the water with the head just above the water surface [26].

\section{STATISTICAL ANALYSIS}

Data were expressed as mean \pm S.E.M. When several treatments were compared, one-way ANOVA was used and post-hoc comparisons between vehicle and drug treated groups were made using Dunnett's multiple comparison test using Graphpad Prism Version 5. In all tests the criterion for significance was $\mathrm{P}<0.05$. 


\section{RESULTS}

\section{Acute toxicity testing}

Salvigenin, rosmanol and cirsimaritin in the dose range of $50-200 \mathrm{mg} / \mathrm{kg}$ did not produce any noticeable effects on grooming, sedation, respiratory arrest, convulsions or muscle activity. Furthermore, no case of lethality was found. Food and water consumption remained normal throughout the test period.

\section{Antinociceptive activity in tail immersion test}

The tail immersion test is most commonly used for assessing the central analgesic effects of substances. All the three compounds showed significant inhibition compared to the control (vehicle). The positive control, tramadol demonstrated $75 \%$ inhibition at a therapeutic dose compared to control. Similarly salvigenin, rosmanol and cirsimaritin showed significant dose dependent inhibition at all doses tested. The maximum inhibition of $74.4,72.83$ and $74.71 \%$ for salvigenin, rosmanol and cirsimaritin, respectively, was observed at $100 \mathrm{mg} / \mathrm{kg}$ for each compound. The maximum inhibition of the tested compounds was comparable to the standard drug tramadol (Table 1).

\section{Hot plate test}

The results (Table 2) show that the treatment of mice with tramadol $(20 \mathrm{mg} / \mathrm{kg}$ i.p.) significantly ( $\mathrm{P}<0.01$; one-way ANOVA, followed by Dunnett's test) increased the latency response in the hot plate test from 30 to 120 minutes after treatment. Similarly salvigenin, rosmanol and cirsimaritin at the doses of $10-100 \mathrm{mg} / \mathrm{kg}$ also caused a significant increase in the latency response from 30 to 120 minutes after treatment $(\mathrm{P}<0.05 ; \mathrm{P}<0.01$; one-way ANOVA followed by Dunnet's test). The results of salvigenin, rosmanol and cirsimaritin at doses of 30 and $100 \mathrm{mg} / \mathrm{kg}$ were comparable to tramadol $(20 \mathrm{mg} / \mathrm{kg})$.

Table 1. Effect of salvigenin, rosmanol and cirsimaritin on mean reaction time by tail immersion method in mice

\begin{tabular}{lllll}
\hline Treatment & Dose $(\mathrm{mg} / \mathrm{kg})$ & Pre treatment $(\mathrm{Sec})$ & $\begin{array}{l}\text { Post treatment } \\
(\mathrm{Sec})\end{array}$ & \% Inhibition \\
\hline Control (Vehicle) & - & $2.2 \pm 0.82$ & $2.2 \pm 0.32$ & - \\
Salvigenin & 10 & $2.2 \pm 0.35$ & $6.3 \pm 0.76$ & $65.07^{* *}$ \\
& 30 & $2.9 \pm 1.2$ & $7.7 \pm 0.78$ & $62.33^{* *}$ \\
& 100 & $2.1 \pm 1.6$ & $8.2 \pm 0.70$ & $74.39^{* * *}$ \\
Rosmanol & 10 & $2.3 \pm 0.36$ & $6.0 \pm 0.66$ & $61.66^{* *}$ \\
& 30 & $2.4 \pm 1.3$ & $6.8 \pm 0.78$ & $64.70^{* *}$ \\
Cirsimaritin & 100 & $2.2 \pm 1.4$ & $8.1 \pm 0.60$ & $72.83^{* * *}$ \\
& 10 & $2.2 \pm 0.5$ & $6.6 \pm 0.70$ & $66.66^{* *}$ \\
Tramadol & 30 & $2.3 \pm 1.3$ & $7.9 \pm 0.64$ & $70.88^{* * *}$ \\
\hline
\end{tabular}

All values are expressed in mean $\pm \operatorname{SEM}(\mathrm{n}=6) .{ }^{*} \mathrm{P}<0.01,{ }^{* * *} \mathrm{P}<0.001$ compared to the vehicle group. Difference between groups was analyzed by analysis of variance (one-way ANOVA followed by Dunnett's test).

Table 2. Effect of salvigenin, rosmanol and cirsimaritin on hot-plate test in mice.

\begin{tabular}{|c|c|c|c|c|c|c|}
\hline \multirow{2}{*}{ Treatment } & \multirow{2}{*}{$\begin{array}{l}\text { Dose } \\
(\mathrm{mg} / \mathrm{kg})\end{array}$} & \multicolumn{5}{|c|}{ Latency of nociceptive response in min (mean \pm SEM) } \\
\hline & & 0 & 30 & 60 & 90 & 120 \\
\hline Vehicle & - & $8.22 \pm 0.23$ & $8.48 \pm 0.18$ & $8.61 \pm 0.43$ & $8.68 \pm 0.29$ & $8.74 \pm 0.51$ \\
\hline \multirow[t]{3}{*}{ Salvigenin } & 10 & $8.32 \pm 0.34$ & $9.45 \pm 0.52 *$ & $9.67 \pm 0.49 *$ & $10.74 \pm 0.67 *$ & $10.63 \pm 0.26^{*}$ \\
\hline & 30 & $8.29 \pm 0.58$ & $10.64 \pm 0.21 * *$ & $11.77 \pm 0.64 * *$ & $12.69 \pm 0.21 * *$ & $13.74 \pm 0.51 * *$ \\
\hline & 100 & $8.30 \pm 0.48$ & $11.54 \pm 0.31 * *$ & $13.7 \pm 0.84 * *$ & $14.49 \pm 0.41 * *$ & $14.74 \pm 0.41 * *$ \\
\hline \multirow[t]{3}{*}{ Rosmanol } & 10 & $8.22 \pm 0.24$ & $9.35 \pm 0.42 *$ & $9.77 \pm 0.39 *$ & $10.84 \pm 0.67 *$ & $11.85 \pm 0.24^{*}$ \\
\hline & 30 & $8.35 \pm 0.58$ & $11.54 \pm 0.31 * *$ & $12.67 \pm 0.44 * *$ & $12.69 \pm 0.31 * *$ & $14.64 \pm 0.41 * *$ \\
\hline & 100 & $8.40 \pm 0.38$ & $12.64 \pm 0.31 * *$ & $14.81 \pm 0.74 * *$ & $14.90 \pm 0.31 * *$ & $14.94 \pm 0.31 * *$ \\
\hline \multirow[t]{3}{*}{ Cirsimaritin } & 10 & $8.42 \pm 0.24$ & $9.35 \pm 0.42 *$ & $10.77 \pm 0.39 *$ & $11.84 \pm 0.67^{*}$ & $11.95 \pm 0.34^{*}$ \\
\hline & 30 & $8.44 \pm 0.28$ & $10.52 \pm 0.41 * *$ & $11.65 \pm 0.34 * *$ & $12.80 \pm 0.41 * *$ & $14.34 \pm 0.35^{* *}$ \\
\hline & 100 & $8.55 \pm 0.38$ & $12.54 \pm 0.21 * *$ & $13.81 \pm 0.74 * *$ & $13.80 \pm 0.51 * *$ & $14.74 \pm 0.41 * *$ \\
\hline Tramadol & 20 & $8.51 \pm 0.37$ & $12.59 \pm 0.74 * *$ & $15.89 \pm 0.52 * *$ & $16.24 \pm 0.23^{* *}$ & $15.62 \pm 0.23 * *$ \\
\hline
\end{tabular}




\section{Tail suspension test}

The effects of salvigenin, rosmanol and cirsimaritin on active behavior in the tail suspension test (TST) are shown in Table 3 . Intraperitoneal administration of the positive control, imipramine at the dose of $60 \mathrm{mg} / \mathrm{kg}$, caused a significant reduction in the immobility time as compared to the vehicle $(\mathrm{P}<0.001)$. Salvigenin, rosmanol and cirsimaritin at the doses of 30 and $100 \mathrm{mg} / \mathrm{kg}$, caused a significant decrease in the immobility time as compared to the vehicle control group $(\mathrm{P}<0.05 ; \mathrm{P}<0.01)$.

\section{Forced swim test}

The effects salvigenin, rosmanol and cirsimaritin on active behavior in the forced swim test (FST) of mice is summarized in Table 4. Intraperitoneal administration of salvigenin, rosmanol and cirsimaritin at doses of 30 and $100 \mathrm{mg} / \mathrm{kg}$ significantly decreased the immobility time in the FST as compared to the control (vehicle) $(\mathrm{P}<0.05$; $\mathrm{P}<0.001$; one-way ANOVA, followed by Dunnett's test). The positive control imipramine 60 $\mathrm{mg} / \mathrm{kg}$, also caused a significant decrease in the immobility time as compared to vehicle $(\mathrm{P}<0.001$; one-way ANOVA followed by Dunnet's test). The effect of salvigenin, rosmanol and cirsimaritin at $100 \mathrm{mg} / \mathrm{kg}$ was comparable to the positive control imipramine.

\section{Elevated plus maze test}

The anxiolytic effects of salvigenin, rosmanol and cirsimaritin or diazepam on behavior in the elevated plus maze using diazepam as a positive control are summarized in figure 2. Salvigenin, rosmanol and cirsimaritin significantly reduced the anxiety in mice. All the three compounds at the doses of 10,30 and $100 \mathrm{mg} / \mathrm{kg}$ i.p. significantly increased the $\%$ open arm entries and $\%$ time spent in open arms of the elevated plus maze (EPM). The highest anxiolytic activity was observed at 10 and $30 \mathrm{mg} / \mathrm{kg}$, after which there was a decline in the anxiolytic activity at higher doses $(100 \mathrm{mg} / \mathrm{kg})$ as evidenced by the decrease in the $\%$ open arm entries and \% time spent in open arms. This reduction in the anxiolytic effect at high dose may be due to the onset of sedative effect at higher doses.

Similarly diazepam $(0.5,1,3 \mathrm{mg} / \mathrm{kg}$, i.p) also increased $\%$ open arm entries $(\mathrm{P}<0.05, \mathrm{P}<0.01$, $\mathrm{P}<0.05$, respectively, and the $\%$ time spent in open arms of the EPM $(\mathrm{P}<0.01, \mathrm{P}<0.001, \mathrm{P}<0.01$, respectively. The anxiolytic effect of diazepam at dose of $3 \mathrm{mg} / \mathrm{kg}$ was also decreased as compared to lower doses of diazepam $(0.5,1 \mathrm{mg} / \mathrm{kg}$, i.p.) indicating the onset of sedative effects at higher doses.

\section{Effect of pentylenetetrazol and flumazenil on the anxiolytic activity of salvigenin, rosmanol and cirsimaritin in the elevated plus maze} Figure 3 shows that the anxiolytic activity of salvigenin, rosmanol and cirsimaritin did not decrease by co-administration of flumazenil (2.5 $\mathrm{mg} / \mathrm{kg}$ ) with salvigenin, rosmanol and cirsimaritin $(10 \mathrm{mg} / \mathrm{kg})$, indicating that the high-affinity benzodiazepine binding site is not involved in the anxiolytic activity induced by these compounds. However, both the \% open arm entries and time spent in open arms were significantly decreased by flumazenil for the diazepam $(1 \mathrm{mg} / \mathrm{kg})$ treated mice. The increase in the \% open arm entries and $\%$ time spent in the open arms of salvigenin, rosmanol and cirsimaritin (10 $\mathrm{mg} / \mathrm{kg})$ was significantly decreased by PTZ (20 mg/kg), suggesting that the effect is mediated by $\mathrm{GABA}_{\mathrm{A}}$ receptors at a site other than the high affinity benzodiazepine binding site.

Table 3: Effect of salvigenin, rosmanol or cirsimaritin on immobility period (sec) of mice using

\begin{tabular}{llll}
\multicolumn{2}{l}{ tail suspension test } & & \\
\hline Group & Treatment & Dose (mg/kg) & Immobility time (sec) \\
\hline 1 & Control & - & $164.5 \pm 12.5$ \\
2 & Salvigenin & 10 & $159.4 \pm 13.5$ \\
3 & & 30 & $125.7 \pm 11.3^{*}$ \\
4 & 100 & $100.5 \pm 10.2^{* *}$ \\
5 & 10 & $155.4 \pm 14.8$ \\
6 & Rosmanol & 30 & $120.3 \pm 12.9^{*}$ \\
7 & 100 & $95.9 \pm 14.4^{* *}$ \\
8 & 10 & $155.8 \pm 13.2$ \\
9 & Cirsimaritin & 30 & $125.3 \pm 10.3^{*}$ \\
10 & 100 & $75.6 \pm 15.1^{* *}$ \\
11 & & 60 & $50.2 \pm 11.6^{* * *}$ \\
\hline All values are expressed in mean \pm SEM (n=6). ${ }^{*} \mathrm{P}<0.05, * * \mathrm{P}<0.01, * * * \mathrm{P}<0.001$ compared to \\
the vehicle group. Difference between groups were analyzed by analysis of variance (one-way \\
ANOVA followed by Dunnett's test).
\end{tabular}


Table 4: Effect of salvigenin, rosmanol or cirsimaritin on immobility period $(\mathrm{sec})$ of mice using forced swimming test

\begin{tabular}{llll}
\hline Group & Treatment & Dose $(\mathbf{m g} / \mathbf{k g})$ & Immobility time (sec) \\
\hline 1 & Control & - & $174.6 \pm 13.5$ \\
2 & Salvigenin & 10 & $169.4 \pm 14.5$ \\
3 & & 30 & $135.7 \pm 12.3^{*}$ \\
4 & & 100 & $70.5 \pm 11.2^{* * *}$ \\
5 & Rosmanol & 10 & $165.4 \pm 15.5$ \\
6 & & 30 & $130.3 \pm 11.4^{*}$ \\
7 & & 100 & $64.9 \pm 12.5^{* * *}$ \\
8 & Cirsimaritin & 10 & $168.8 \pm 12.2$ \\
9 & & 30 & $135.3 \pm 11.3^{*}$ \\
10 & 100 & $65.6 \pm 14.1^{* * *}$ \\
11 & & 60 & $60.2 \pm 12.6^{* * *}$ \\
\hline
\end{tabular}

All values are expressed in mean \pm SEM $(n=6) . * \mathrm{P}<0.05,{ }^{*} * * \mathrm{P}<0.001$ compared to the vehicle group. Difference between groups were analyzed by analysis of variance (one-way ANOVA) followed by Dunnett's test.

A
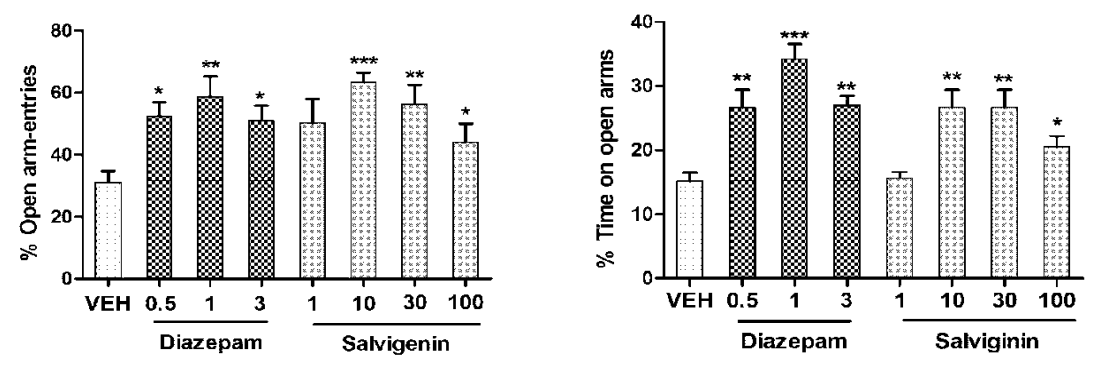

B
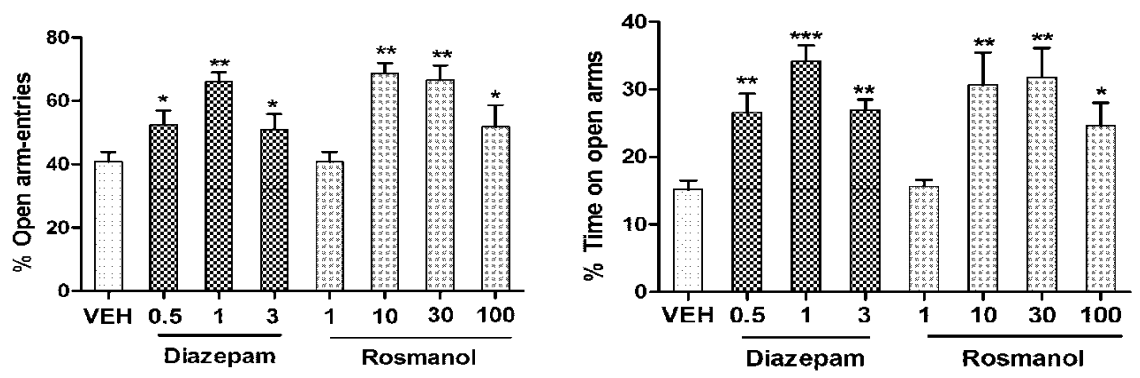

C
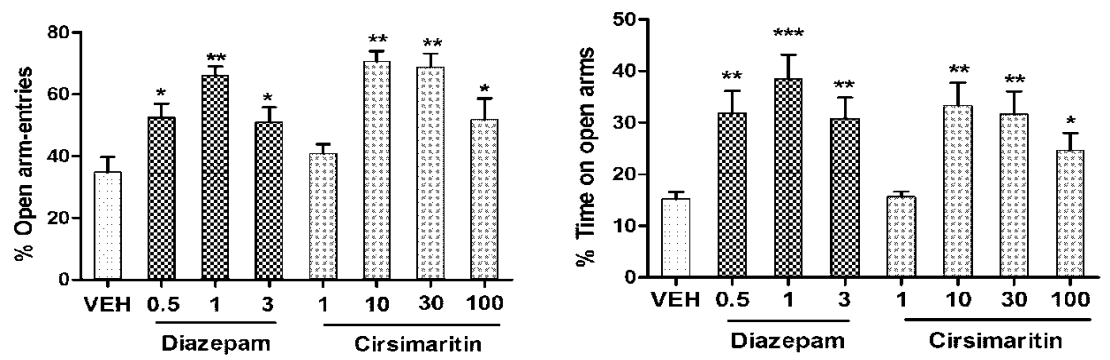

Figure 2. Effect of salvigenin, rosmanol and cirsimaritin and diazepam on the behavior of mice in the elevated plus maze (A) \% open-arm entries (Left panel) \% time spent in open-arms (Right panel) registered over a session of 5 min, after 20 min of an i.p injection of salvigenin $(1,10,30$ and $100 \mathrm{mg} / \mathrm{kg}(\mathbf{B}) \%$ open-arm entries (Left panel) \% time spent in openarms (Right panel) registered over a session of $5 \mathrm{~min}$, after $20 \mathrm{~min}$ of an i.p injection of rosmanol $(1,10,30 \mathrm{and} 100 \mathrm{mg} / \mathrm{kg}$ b.w.), diazepam $(0.5,1$ and $3 \mathrm{mg} / \mathrm{kg}$ ) or vehicle. (C) \% open-arm entries (Left panel) \% time spent in open-arms (Right panel) registered over a session of $5 \mathrm{~min}$, after $20 \mathrm{~min}$ of an i.p injection of cirsimaritin $(1,10,30 \mathrm{and} 100 \mathrm{mg} / \mathrm{kg}$. Columns represent mean \pm SEM ( $\mathrm{n}=6$ /group). *: $\mathrm{P}<0.05$, **: $\mathrm{P}<0.01$, ***: $\mathrm{P}<0.001$ compared with vehicle group using one-way ANOVA followed by Dunnett's test. 
A

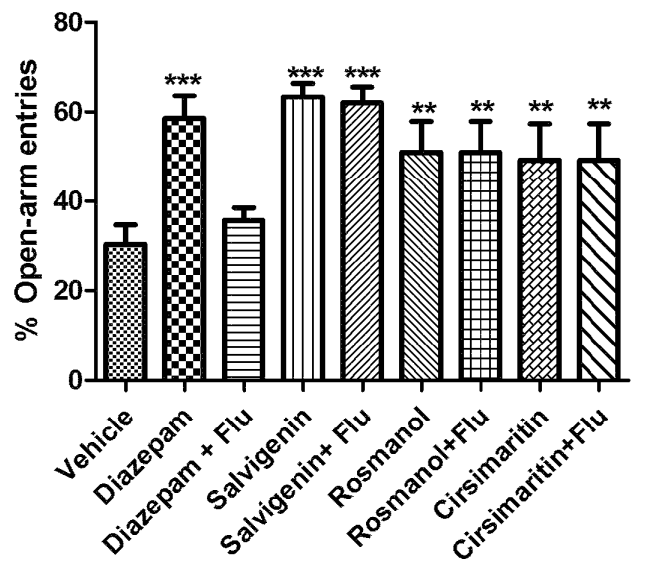

Treatment $(\mathrm{mg} / \mathrm{kg})$

B

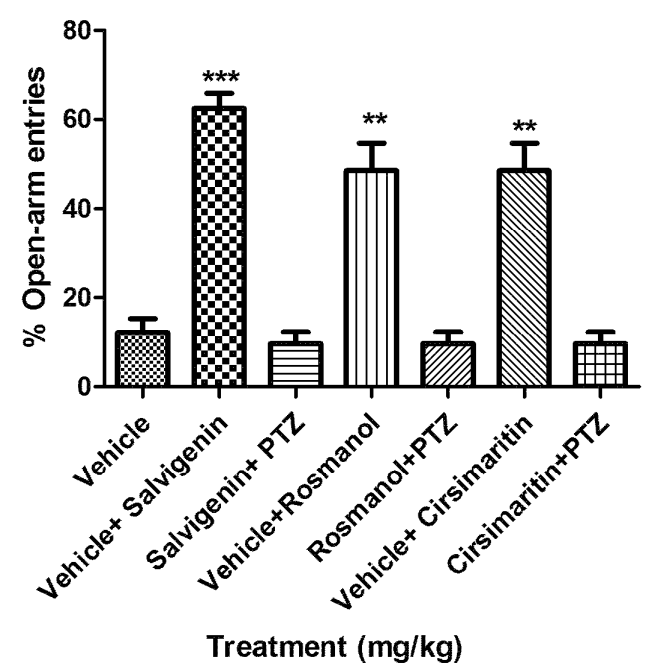

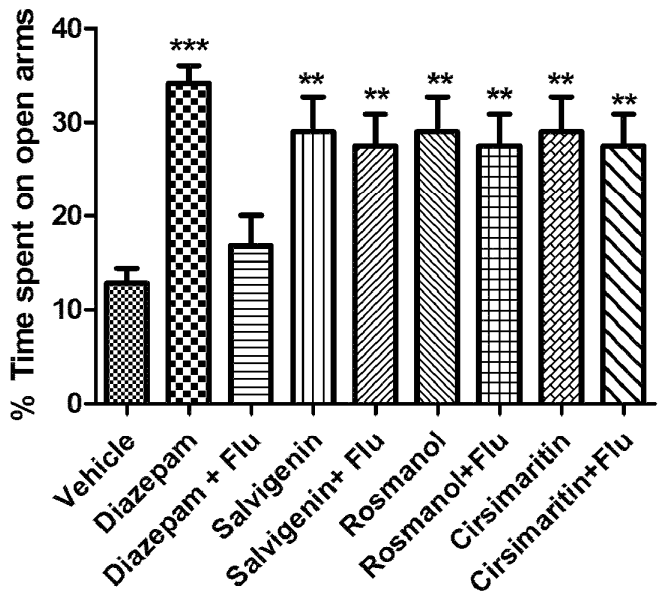

Treatment $(\mathrm{mg} / \mathrm{kg})$

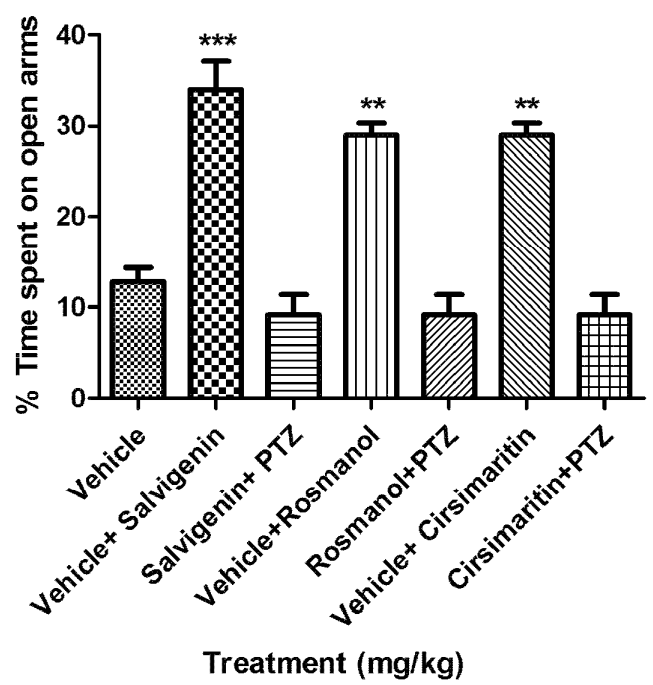

Figure 3. Effect of flumazenil and PTZ on the anxiolytic activity of salvigenin, rosmanol and cirsimaritin in the elevated plus maze. (A) \% entries in open-arms (Left panel) \% time spent in open-arms (Right panel) registered over a session of $5 \mathrm{~min}$, after $20 \mathrm{~min}$ of an i.p injection of vehicle, diazepam $(1 \mathrm{mg} / \mathrm{kg})$ and salvigenin, rosmanol or cirsimaritin $(10 \mathrm{mg} / \mathrm{kg})$ in the presence of flumazenil $(2.5 \mathrm{mg} / \mathrm{kg})$. (B) \% entries in open-arms (Left panel) \% time spent in open-arms (Right panel) registered over a session of $5 \mathrm{~min}$, after $20 \mathrm{~min}$ of an i.p injection of vehicle, diazepam ( $1 \mathrm{mg} / \mathrm{kg})$ and salvigenin, rosmanol or cirsimaritin $(10 \mathrm{mg} / \mathrm{kg})$ in the presence of PTZ $(20 \mathrm{mg} / \mathrm{kg})$. Column express $\mathrm{mean} \pm \mathrm{SEM}$ ( $\mathrm{n}=6 / \mathrm{group}), n=6$ per group. *: $\mathrm{P}<0.05, * *: \mathrm{P}<0.01$, ***: $\mathrm{P}<0.001$ compared with vehicle control group using one-way ANOVA post Dunnett's test.

\section{Effects of salvigenin, rosmanol and} cirsimaritin in light dark/dark box test

The behavioral effects of diazepam, salvigenin, rosmanol and cirsimaritin in the light dark box test are shown in figure 4 . The results indicate that salvigenin, rosmanol and cirsimaritin at the doses of 10,30 and $100 \mathrm{mg} / \mathrm{kg}$ i.p., significantly increased the time spent in the light compartment and the number of transitions between light and dark compartments $(\mathrm{P}<0.001, \mathrm{P}<0.01, \mathrm{P}<0.05$, $\mathrm{n}=6$, one-way ANOVA followed by Dunnett's test).
However, similar to the EPM, the anxiolytic effect of all the three compounds was decreased at the higher dose $(100 \mathrm{mg} / \mathrm{kg})$, suggesting the onset of sedative effects.

The reference drug diazepam at the dose level (0.5, 1 and $3 \mathrm{mg} / \mathrm{kg}$ i.p.) significantly $(\mathrm{P}<0.01$, $\mathrm{P}<0.001, \quad \mathrm{P}<0.001, \quad$ respectively) and dose dependently increased the time spent in the light area of the light dark box, indicating anti-anxiety activity and confirming that the paradigm is valid. 
A
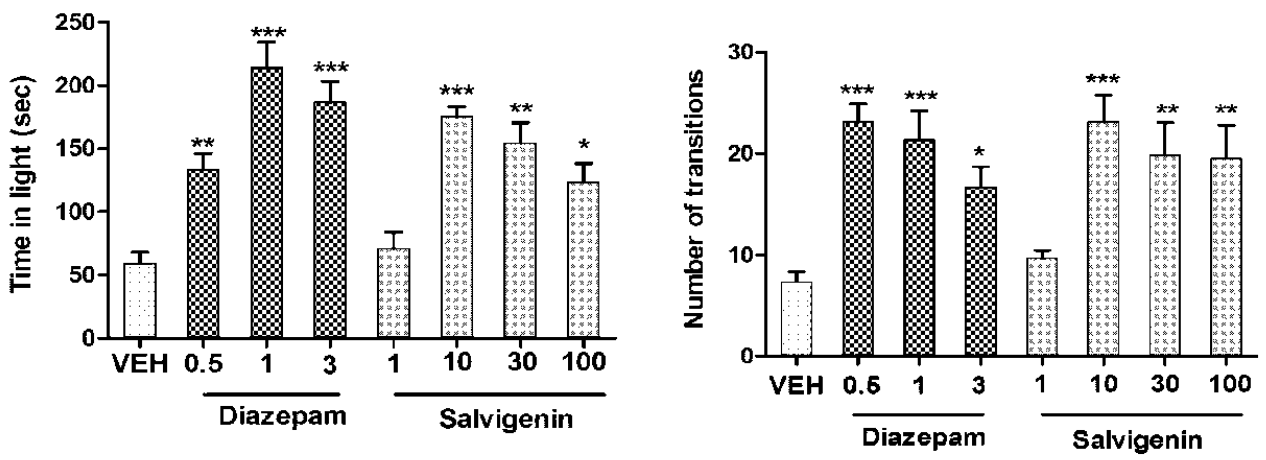

B
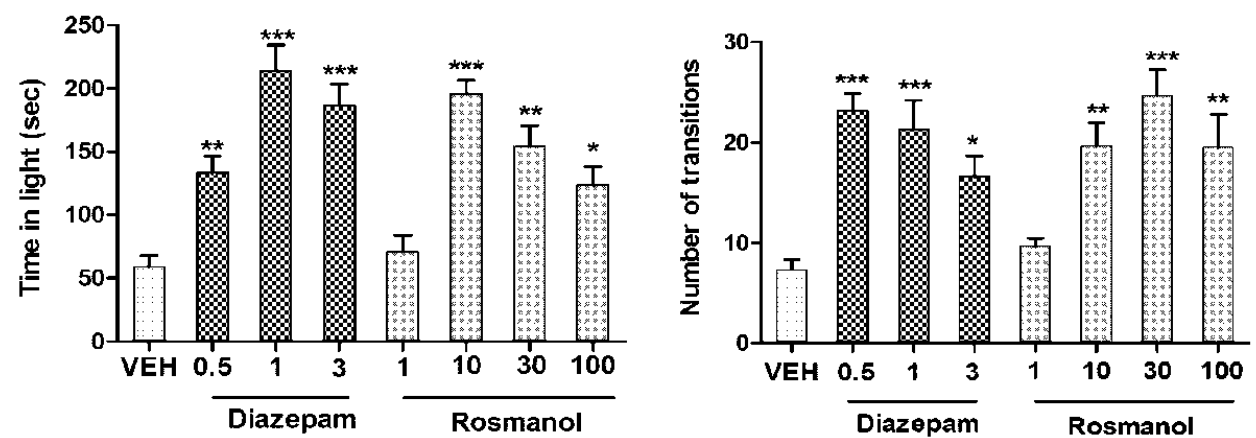

C
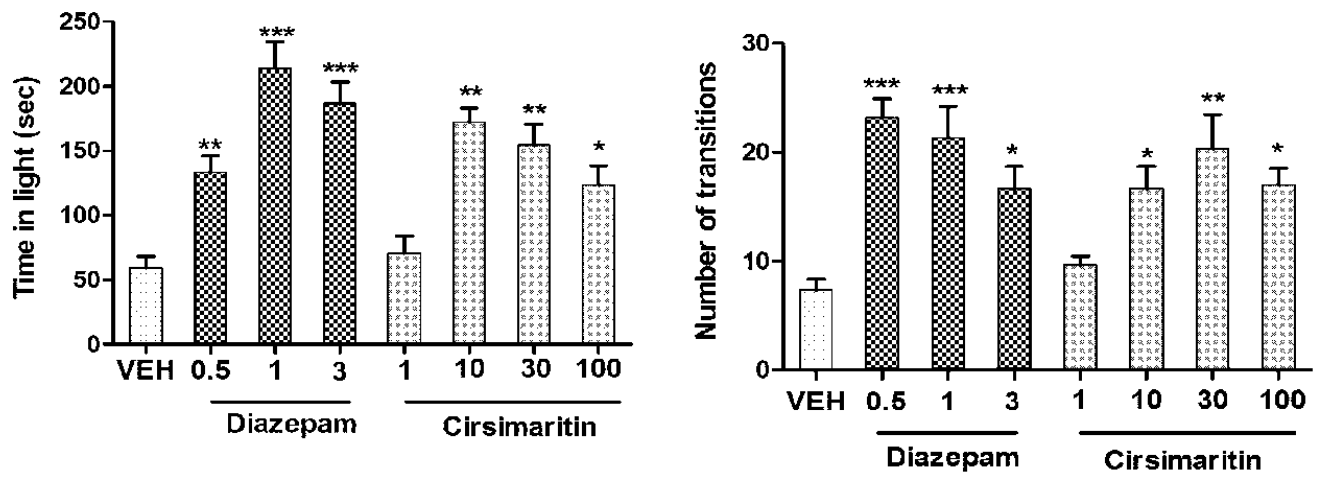

Figure 4. Effect of salvigenin, rosmanol and cirsimaritin and diazepam on the behavior of mice in the light dark box test (A) Time spent in lit area (Left panel) number of transitions (Right panel), recorded over a session of 5 min, after 20 min of an i.p. injection of salvigenin $(1,10,30$ and $100 \mathrm{mg} / \mathrm{kg})$, diazepam $(0.5,1$ and $3 \mathrm{mg} / \mathrm{kg}$ ) or vehicle. (B) time spent in lit area (Left panel) number of transitions (Right panel), recorded over a session of 5 min, after 20 min of an i.p. injection of rosmanol $(1,10,30$ and $100 \mathrm{mg} / \mathrm{kg})$, diazepam $(0.5,1$ and $3 \mathrm{mg} / \mathrm{kg})$ or vehicle. (C) time spent in lit area (Left panel) number of transitions (Right panel), recorded over a session of $5 \mathrm{~min}$, after $20 \mathrm{~min}$ of an i.p. injection of cirsimaritin (1, $10,30$ and $100 \mathrm{mg} / \mathrm{kg})$, diazepam $(0.5,1$ and $3 \mathrm{mg} / \mathrm{kg})$ or vehicle. Values are express mean $\pm \mathrm{SEM}$ ( $\mathrm{n}=6 /$ group). ${ }^{*}: \mathrm{P}<0.05$, **: $\mathrm{P}<0.01, * * *: \mathrm{P}<0.001$ compared with vehicle group using one-way ANOVA followed by Dunnett's test.

\section{DISCUSSION}

Salvigenin, rosmanol and cirsimaritin were evaluated for various neuropharmacological activities in mouse models. The central analgesic effects of salvigenin, rosmanol and cirsimaritin were determined in hot plate and tail immersion tests. Both hot plate and tail immersion tests are of thermal stimuli and an increase in the reaction time is generally considered to be an important 
parameter for the evaluation of central antinociceptive activity [33]. Salvigenin, rosmanol and cirsimaritin exerted significant antinociceptive effects in both hot plate and tail immersion tests at the dose level of $10-100 \mathrm{mg} / \mathrm{kg}$. The cellular and neural mechanisms underlying pain responses elicited involves interplay of a number of neurotransmitters and ion channels [35, 36], and the central analgesic effects of salvigenin, rosmanol and cirsimaritin were not antagonized by the opioid receptor antagonist naloxone. This indicates that the central analgesic effects of salvigenin, rosmanol and cirsimaritin may be exerted via one or more of several proposed nonopioid mechanisms such as blockade of voltagegated $\mathrm{Na}^{+}$channels, activation of the noradrenergic inhibitory system, enhancement of GABAergic and/or serotonergic systems [34].

The tail suspension test and the forcedswimming test are well known models of depression sensitive to all classes of antidepressant including tricyclic antidepressants, monoamine oxidase inhibitor and selective serotonin reuptake inhibitors. Both tests are widely used screening methods for antidepressants in mice [25, 37]. Increasing evidence has suggested that the GABAergic system is also implicated in the pathophysiology of depression, with patients suffering from depression shown to have deficient GABA levels as well as decreased cortical GABAA receptors. Thus substances which could positively affect this system may have potential effects on depression [38]. Salvigenin, rosmanol and cirsimaritin have previously been shown to have a biphasic mode of action at GABA receptors, potentiating GABA-evoked currents at low concentrations of GABA [18], so these compounds were investigated for their antidepressant potential. Salvigenin, rosmanol and cirsimaritin exerted significant antidepressant effect as evidenced by the reduction of immobility time in both the tail suspension test and the forced swimming test.

Anxiety is a state of excessive fear that is characterized by motor tension, sympathetic hyperactivity, apprehension and vigilance syndromes [39]. The elevated plus maze and light dark test are routinely used for the assessment of anxiolytic activity of substances in rodents [23, 40]. In this study salvigenin, rosmanol and cirsimaritin exerted significant anxiolytic effects at the doses of $10-100 \mathrm{mg} / \mathrm{kg}$ in both the elevated plus maze and light dark tests. There was a slight reduction in the anxiolytic effect at $100 \mathrm{mg} / \mathrm{kg}$, which may indicate the onset of sedative effect at high doses. Such biphasic effects have previously been observed with other synthetic flavonoids such as 2-methoxy6-methylflavone (2’MeO6MF) [23]. We have previously shown that salvigenin, rosmanol and cirsimaritin all appear to elicit positive modulation of low concentrations of GABA via three different sites on $\mathrm{GABA}_{\mathrm{A}}$ receptors [18]. Despite the positive modulation of $\alpha 1 \beta 2 \gamma 2 \mathrm{~L} \mathrm{GABA_{A }}$ receptors by rosmanol being sensitive to flumazenil [18], the anxiolytic effect exerted by salvigenin, rosmanol and cirsimaritin was not antagonized by flumazenil. However, it was significantly decreased by the coadministration of PTZ, indicating that the effect is likely to be mediated through $\mathrm{GABA}_{\mathrm{A}}$ receptors but independently of the high-affinity benzodiazepine binding site.

Salvigenin, rosmanol and cirsimaritin have been previously shown to have biphasic modulation of $\alpha 1 \beta 2 \gamma 2 \mathrm{~L}$ GABA receptors, and have demonstrated CNS activity in mouse models of antinociception, antidepressant and anxiolysis. We have shown that the anxiolytic activity is likely to be mediated via $\mathrm{GABA}_{\mathrm{A}}$ receptors. However, further studies are required to investigate possible mechanisms of action of these compounds in analgesia and depression and to investigate the effect of these compounds at $\mathrm{GABA}_{\mathrm{A}}$ receptor subtypes other than $\alpha 1 \beta 2 \gamma 2 \mathrm{~L} \mathrm{GABA}_{\mathrm{A}}$ receptors.

\section{ACKNOWLEDGMENTS}

A. A. gratefully acknowledges the financial support of the Government of Australia for an Endeavour International Postgraduate Research Scholarship (EIPRS).

\section{REFERENCES}

1. Gonzalez-Trujano ME, Pena EI, Martinez AL, Moreno J, Guevara-Fefer P, Deciga-Campos M, et al. Evaluation of the antinociceptive effect of Rosmarinus officinalis L. using three different experimental models in rodents. J Ethnopharmacol. 2007;111:476-82. Epub 2007/01/16.

2. Erkan N, Ayranci G, Ayranci E. Antioxidant activities of rosemary (Rosmarinus Officinalis L.) extract, blackseed (Nigella sativa L.) essential oil, carnosic acid, rosmarinic acid and sesamol. Food Chem. 2008;110:76-82.

3. Duke JA. Alzheimaretto. J Med Food. 1998;1:53.

4. Perry EK, Pickering AT, Wang WW, Houghton P, Perry NSL. Medicinal Plants and Alzheimer's Disease: Integrating Ethnobotanical and Contemporary Scientific Evidence. The Journal of Alternative and Complementary Medicine. 1998;4:419.

5. Ozarowski M, Mikolajczak PL, Bogacz A, Gryszczynska A, Kujawska M, Jodynis-Liebert J, et al. Rosmarinus officinalis L. leaf extract improves memory impairment and affects acetylcholinesterase and butyrylcholinesterase activities in rat brain. Fitoterapia. 2013;91:261-71. 
6. Kosaka K, Yokoi T. Carnosic acid, a component of rosemary (Rosmarinus officinalis L.), promotes synthesis of nerve growth factor in T98G human glioblastoma cells. Biol Pharm Bull. 2003;26:16202. Epub 2003/11/06.

7. Crutcher KA, Scott SA, Liang S, Everson WV, Weingartner J. Detection of NGF-like activity in human brain tissue: increased levels in Alzheimer's disease. J Neurosci. 1993;13:2540-50. Epub 1993/06/01.

8. Hold KM, Sirisoma NS, Ikeda T, Narahashi T, Casida JE. Alpha-thujone (the active component of absinthe): gamma-aminobutyric acid type A receptor modulation and metabolic detoxification. Proc Natl Acad Sci USA. 2000;97:3826-31. Epub 2000/03/22.

9. Takeda H, Tsuji M, Inazu M, Egashira $T$, Matsumiya T. Rosmarinic acid and caffeic acid produce antidepressive-like effect in the forced swimming test in mice. Eur $\mathrm{J}$ Pharmacol. 2002;449:261-7. Epub 2002/08/09.

10. Takeda H, Tsuji M, Miyamoto J, Matsumiya T. Rosmarinic acid and caffeic acid reduce the defensive freezing behavior of mice exposed to conditioned fear stress. Psychopharmacology (Berl). 2002;164:233-5. Epub 2002/10/31.

11. Pereira P, Tysca D, Oliveira P, da Silva Brum LF, Picada JN, Ardenghi P. Neurobehavioral and genotoxic aspects of rosmarinic acid. Pharmacol Res. 2005;52:199-203. Epub 2005/07/20.

12. Kim SJ, Kim JS, Cho HS, Lee HJ, Kim SY, Kim S, et al. Carnosol, a component of rosemary (Rosmarinus officinalis L.) protects nigral dopaminergic neuronal cells. Neuroreport. 2006;17:1729-33. Epub 2006/10/19.

13. Krnjevic K, Schwartz S. The action of gammaaminobutyric acid on cortical neurones. Experimental brain research Experimentelle Hirnforschung. 1967;3:320-36.

14. Ticku MK. Differences in gamma-aminobutyric acid receptor sensitivity in inbred strains of mice. $\mathrm{J}$ Neurochem. 1979;33:1135-8.

15. Hanrahan JR, Chebib M, Johnston GAR. Flavonoid modulation of $\mathrm{GABA}_{\mathrm{A}}$ receptors. Br J Pharmacol. 2011;163:234-45.

16. Walters RJ, Hadley SH, Morris KDW, Amin J. Benzodiazepines act on GABAA receptors via two distinct and separable mechanisms. Nat Neurosi. 2000;3:1274-81.

17. Kavvadias D, Monschein V, Sand P, Riederer P, Schreier P. Constituents of Sage (Salvia officinalis) with in vitro Affinity to Human Brain Benzodiazepine Receptor. Planta Med. 2003;69:113-7.

18. Abdelhalim A, Chebib M, Aburjai T, Johnston GAR, Hanrahan JR. GABAA Receptor Modulation by Compounds Isolated from Salvia triloba L. Adv Biol Chem. 2014;4:148-59. Epub 21 March 2014.

19. Adebiyi OE, Abatan MO. Phytochemical and acute toxicity of ethanolic extract of Enantia chlorantha (oliv) stem bark in albino rats. Interdiscip Toxicol. 2013;6:145-51.
20. Janssen PA, Niemegeers CJE, Dony JGH. The inhibitory effect of fentanyl and other morphinelike analgesics on the warm water induced tail withdrawal reflex in rats. Arzneimittelforschung. 1963;13:502-7.

21. Tita B, Abdel-Haq H, Vitalone A, Mazzanti G, Saso L. Analgesic properties of Epilobium angustifolium, evaluated by the hot plate test and the writhing test. Farmaco. 2001;56(5-7):341-3. Epub 2001/08/03.

22. Squires RF, Saederup E, Crawley JN, Skolnick P, Paul SM. Convulsant potencies of tetrazoles are highly correlated with actions on GABA / benzodiazepine / picrotoxin receptor complexes in brain. Life Sci. 1984;35:1439-44.

23. Karim N, Curmi J, Gavande N, Johnston GAR, Hanrahan JR, Tierney ML, et al. 2'-Methoxy-6methylflavone: A novel anxiolytic and sedative with subtype selective activating and modulating actions at GABA-A receptors. Br J Pharmacol. 2012;165:880-96.

24. Bourin M, Hascoet M. The mouse light/dark box test. Eur J Pharmacol. 2003;463(1-3):55-65. Epub 2003/02/26.

25. Steru L, Chermat R, Thierry B, Simon P. The tail suspension test: a new method for screening antidepressants in mice. Psychopharmacology (Berl). 1985;85(3):367-70. Epub 1985/01/01.

26. Porsolt RD, Anton G, Blavet N, Jalfre $M$. Behavioural despair in rats: a new model sensitive to antidepressant treatments. Eur J Pharmacol. 1978;47(4):379-91. Epub 1978/02/15.

27. Marder M, Viola H, Wasowski C, Fernández S, Medina JH, Paladini AC. 6-Methylapigenin and hesperidin: new valeriana flavonoids with activity on the CNS. Pharmacol Biochem Behav. 2003;75:537-45.

28. Fernandez SP, Wasowski C, Paladini AC, Marder M. Synergistic interaction between hesperidin, a natural flavonoid, and diazepam. Eur J Pharmacol. 2005;512:189-98. Epub 2005/04/21.

29. Fernandez SP, Wasowski C, Loscalzo LM, Granger RE, Johnston GA, Paladini AC, et al. Central nervous system depressant action of flavonoid glycosides. Eur J Pharmacol. 2006;539:168-76. Epub 2006/05/16.

30. Martínez MC, Fernandez SP, Loscalzo LM, Wasowski C, Paladini AC, Marder M, et al. Hesperidin, a flavonoid glycoside with sedative effect, decreases brain pERK1/2 levels in mice. Pharmacol Biochem Behav. 2009;92:291-6.

31. Loscalzo LM, Wasowski C, Paladini AC, Marder $\mathrm{M}$. Opioid receptors are involved in the sedative and antinociceptive effects of hesperidin as well as in its potentiation with benzodiazepines. Eur J Pharmacol. 2008;580:306-13. Epub 2007/12/01.

32. Agarwal OP. The anti-inflammatory action of nepitrin, a flavonoid. Agents Actions. 1982;12:298302. Epub 1982/07/01.

33. Rujjanawate C, Kanjanapothi D, Panthong A. Pharmacological effect and toxicity of alkaloids 
from Gelsemium elegans Benth. J Ethnopharmacol. 2003;89:91-5.

34. Waszkielewicz AM, Gunia A, Szkaradek N, Sloczynska K, Krupinska S, Marona H. Ion channels as drug targets in central nervous system disorders. Curr Med Chem. 2013;20(10):1241-85. Epub 2013/02/16.

35. Chang FC, Tsai HY, Yu MC, Yi PL, Lin JG. The central serotonergic system mediates the analgesic effect of electroacupuncture on ZUSANLI (ST36) acupoints. J Biomed Sci. 2004;11(2):179-85. Epub 2004/02/18.

36. Klusa V, Germane S, Svirskis S, Opmane B, Wikberg JE. The gamma(2)-MSH peptide mediates a central analgesic effect via a GABA-ergic mechanism that is independent from activation of melanocortin receptors. Neuropeptides. 2001;35(1):50-7. Epub 2001/05/11.

37. Cryan JF, Markou A, Lucki I. Assessing antidepressant activity in rodents: recent developments and future needs. Trends Pharmacol Sci. 2002;23(5):238-45. Epub 2002/05/15.

38. Mohler H. The GABA system in anxiety and depression and its therapeutic potential. Neuropharmacology. 2012;62(1):42-53. Epub 2011/09/06.

39. Akanmu MA, Olowookere TA, Atunwa SA, Ibrahim BO, Lamidi OF, Adams PA, et al. Neuropharmacological effects of Nigerian honey in mice. Afr J Tradit Complement Altern Med. 2011;8(3):230-49. Epub 2011/01/01.

40. Karim N, Gavande N, Wellendorph P, Johnston GA, Hanrahan JR, Chebib M. 3-Hydroxy-2'methoxy-6-methylflavone: a potent anxiolytic with a unique selectivity profile at $\mathrm{GABA}_{\mathrm{A}}$ receptor subtypes. Biochem Pharmacol. 2011;82:1971-83. 